\title{
A new species of soft-winged flower beetle of the genus Attalogonia Wittmer, 1976 (Coleoptera: Malachiidae: Apalochrini) from Argentina
}

\author{
S.E. Tshernyshev ${ }^{1,2}$ \\ ${ }^{1}$ Institute of Animal Systematics and Ecology, Russian Academy of Sciences, Siberian Branch, \\ Frunze Street, 11, Novosibirsk, 630091, Russia.E-mail: sch-sch@mail.ru \\ ${ }^{2}$ Tomsk State University, Lenina prospekt, 36, Tomsk, 634050, Russia.
}

ABSTRACT: A new species, Attalogonia reshetnikovi Tshernyshev sp.n., is described in the tribe Attalini (Coleoptera: Malachiidae) from Cordoba Province in Argentina. The distinctive colouration of the elytra with black-brown disc and yellow-orange suture and edges, the yellow-orange head and pronotum with small black areas and striae, and the narrow, elongate, simple, slightly curved ventrally aedeagus with a pointed triangular lamella at the apex, two strong bristles in the inner sac differentiate the new species from all known congeners of the species-group. A detailed description of a new species is provided, together with illustrations of external appearance, antenna, head and pronotum, anterior tasus, and genitalia, and a distribution map of the species.

How to cite this article: Tshernyshev S.E. 2020. A new species of soft-winged flower beetle of the genus Attalogonia Wittmer, 1976 (Coleoptera: Malachiidae: Apalochrini) from Argentina // Invert. Zool. Vol.17. No.1. P.71-75. doi: 10.15298/invertzool.17.1.07

KEY WORDS: Malachiidae, Attalini, Attalogonia, taxonomy, new species, Argentina.

\section{Новый вид жуков малашек рода Attalogonia Wittmer, 1976 (Coleoptera: Malachiidae: Apalochrini) из Аргентины}

\section{С.Э. Чернышёв ${ }^{1,2}$}

\author{
${ }^{1}$ Институт систематики и экологии животных СО РАН, ул. Фрунзе, 11, Новосибирск, \\ 630091, Россия.E-mail: sch-sch@mail.ru \\ ${ }^{2}$ Томский государственный университет, проспект Ленина, 36, Томск, 634050, Россия.
}

РЕЗЮМЕ: Из провинции Кордова в Аргентине описан новый вид жуков малашек трибы Attalini (Coleoptera: Malachiidae) - Attalogonia reshetnikovi Tshernyshev sp.n. Новый вид отличается следующими признаками: надкрылья серо-черные с желтооранжевым окаймлением, более широким у щитка, голова, переднеспинка и щиток желто-оранжевые, задняя часть головы с черным продольным пятном, переднеспинка с черной продольной узкой полосой посередине, эдеагус узкий, удлиненный, почти прямой, слабо изогнут дорзо-вентрально у вершины с треугольной заостренной ламеллой, с двумя длинными рожковидными щетинками внутри. Приводится детальное описание, иллюстрации внешнего вида, усиков, головы и переднеспинки, передней лапки и гениталий самца, дана карта с указанием места сбора вида. 
Как цитировать эту статью: Tshernyshev S.E. 2020. A new species of soft-winged flower beetle of the genus Attalogonia Wittmer, 1976 (Coleoptera: Malachiidae: Apalochrini) from Argentina // Invert. Zool. Vol.17. No.1. P.71-75. doi: 10.15298/invertzool.17.1.07

КЛЮЧЕВЫЕ СЛОВА: Malachiidae, Attalini, Attalogonia, таксономия, новый вид, Аргентина.

\section{Introduction}

Species of Attalogonia Wittmer, 1976 are common representatives of the tribe Attalini in the New World fauna; however, members of the Attalini are distributed throughout the world with the exception of the most extreme regions of arid inner continental and arctic deserts, beetles are usual residents of moist and warm landscapes of South Asia. Single specimens often occur when collecting beetles in biotopes with arborescent vegetation mainly located near water reservoirs of different types, such preferences probably explaining the presence of ancestral forms in Amber inclusions. Attalini probably originated from the ancestor tribe Palpattalini (Tshernyshev, 2016, 2020), and retain such external characters as a complicated elongate and curved pygidium, long and thin antennae, well developed wings, and an elongated soft body adapted for active movement. Currently, the tribe includes about 500 species, including mountain endemics in Tibet, Himalaya, Altai and other locations.

The genus Attalogonia Wittmer, 1976 was initially described as a subgenus of the genus Attalus Erichson, 1840 due to its similar external appearance, but in view of several good differential characters a separate genus was recognised (Constantin, 2013), namely: body slightly widened and looks truncated or restricted, inter-ocular area of head slightly impressed, finely and distinctly marginated at sides, eyes simple, round-oval and strongly protruding, second antennomere as long as the third antennomere, a bilaciniate 8th ultimate abdominal ventrite, each lobe with flat and curved tip, aedeagus narrow, elongate, simple, slightly curved ventrally at apex, with a pointed triangular lamella at the tip and several strong curved bristles inside. Species of Attalus s.str. recorded from South America should probably be transferred to Attalogonia Wittmer or to one of the other closely related genera of Attalini to be found in this country.

Currently, 17 species are included in the genus Attalogonia Wittmer, 1976, namely $A$. basalis (Erichson, 1840) and A. borgmeieri Wittmer, 1976 recorded from Colombia or Venezuela, A. plicatus (Champion, 1914) from Mexico, A. grandis Wittmer, 1992, from Peru, A. sergefernandezi Constantin, 2013, A. guyanensis Constantin, 2013 and A. saulensis Constantin, 2013 from Guyana, A. bilineatithorax (Pic, 1910), A. brasiliensis (Pic, 1903), A. gounellei (Pic, 1903), A. jatayensis (Pic, 1903) and A. smithi Wittmer, 1992 from Brazil, A. carinatus (Gorham, 1886) from Panama, $A$. alticola (Wittmer, 1941), A. coroicosus (Pic, 1928 ) and A. schenklingi (Pic, 1927) from Bolivia, and A. denieri Wittmer, 1942 from Argentina. Most of the species were described from single specimens of males and referred to as locally distributed (Erichson, 1840; Gorham, 1886; Pic, 1903, 1910, 1927, 1928; Champion, 1914; Wittmer, 1941, 1942, 1976, 1992; Constantin, 2013).

Another species of Attalogonia Wittmer was collected during a 2019 expedition to Argentina by entomologists from Barnaul and Novosibirsk in Russia. The specimen represents a male with distinctively coloured elytra, a black-brown disc with yellow-orange suture and edges, pronotum and head yellow-orange with small black striae. The aedeagus and ultimate urites are a different shape to those in other species of the genus. Further study of the external appearance and genitalia allow consider a new species, Attalogonia reshetnikovi Tshernyshev sp.n., which is described below. 


\section{Material and methods}

The beetle was studied using an Amscope trinocular stereomicroscope (Ultimate Trinocular Zoom Microscope 6.7X-90X Model ZM2TY) and digital photographs were taken using a Carl Zeiss Stemi 2000 trinocular microscope and the AxioVision programme. Male genitalia, embedded in DMHF (Dimethyl hydantoin formaldehyde), were mounted onto a transparent card and pinned under the specimen. Specimens have been deposited in the author's collection (SCH) which is housed in the Institute of Animal Systematics and Ecology, Siberian Branch of the Russian Academy of Sciences, Novosibirsk, Russia.

\section{Results}

Family Malachiidae Fleming, 1821

Subfamily Malachiinae Fleming, 1821

Tribe Attalini Abeille de Perrin, 1890

Genus Attalogonia Wittmer, 1976

\section{Attalogonia reshetnikovi Tshernyshev sp.n. Fig. $1 \mathrm{~A}-\mathrm{K}$.}

MATERIAL. Argentina: Holotype, male, Cordoba Province, Quilino environce, $30^{\circ} 13^{\prime}$ $7^{\prime \prime N}$ 64²9'16"E, 18.X.2019, leg. S. Reshetnikov.

DESCRIPTION. Holotype, male (Fig. 1A, B). Body elongate, subparallel, not wide, slightly expanded posteriorly.

Head excepting narrow black base, 1-3 antennomeres beneath, palpae with black apical palpomere, pronotum with longitudinal black narrow macula in the middle, scutellum, suture of elytra evenly narrowing to apical part and narrow edges of external sides of elytra, underside of the body with black sides of the basal ventrites, coxae, anterior femora excepting black outer sides distally, basal half of intermediate and posterior femorae yellow-orange, body black-brown, median part of each elytron with oval lighter spot on black background. Vesicles yellow, and thoracic mesepimera yellow-dark brown apical side.
Head (Fig. 1C, D) narrower than pronotum, flat, inter-ocular area slightly impressed, finely marginate at sides and trapeziform-shaped, eyes simple, not large, round-oval, strongly protruding, bare; genae short and straight; clypeus narrow, transverse, straight; labrum narrow, transverse; palpi simple with apical segment slightly widened and sub-cylindrical; surface of head sparsely and finely punctured, lacking microsculpture, covered with white fine adpressed pubescence, several long erect dark hairs are visible behind eyes near pronotum and along distal side of the clypeus.

Antennae filiform, slightly dentate, with rectangular and triangular intermediate antennomeres (Fig. 1,E), 1.44 mm long, almost completely reaching the middle of elytra; 1 st antennomere slightly enlarged, clavate, 2 nd antennomere oval-triangular, 1.5 times as long as the $1 \mathrm{st}$ antennomere, and the same length as the $3 \mathrm{rd}$, 3rd-10th antennomeres triangular, of the same length, apical one is elongate, 1.3 times as long as the 10th, oval, narrowed and evenly rounded at apex; surface densely covered with not long dark semi-erect hairs.

Pronotum not narrowed at base, almost completely equilateral with evenly rounded angles and sides, convex, very narrowly depressed along the basal margin; margination distinct at basal and literal sides and fine at the anterior side; surface sparsely finely punctured, with smoothed and indistinct microsculpture, shining, evenly covered with semi-erect white hairs.

Scutellum trapezoid with triangular apex, small and narrow, transversal, almost completely covered by pronotum, sparsely punctured and covered with white pubescence.

Elytra almost completely covering abdomen, sub-parallel, slightly expanded just behind the middle, at base slightly wider than pronotum; humeri small, indistinct, slightly protruding; apices evenly rounded, simple; disc distinctly marginate on external sides and along suture, epipleura narrow, not widened at base; surface dull, densely and finely punctured, with smooth microsculpture, evenly covered with white-grey semi-erect pubescence.

Hind wings normally developed. 


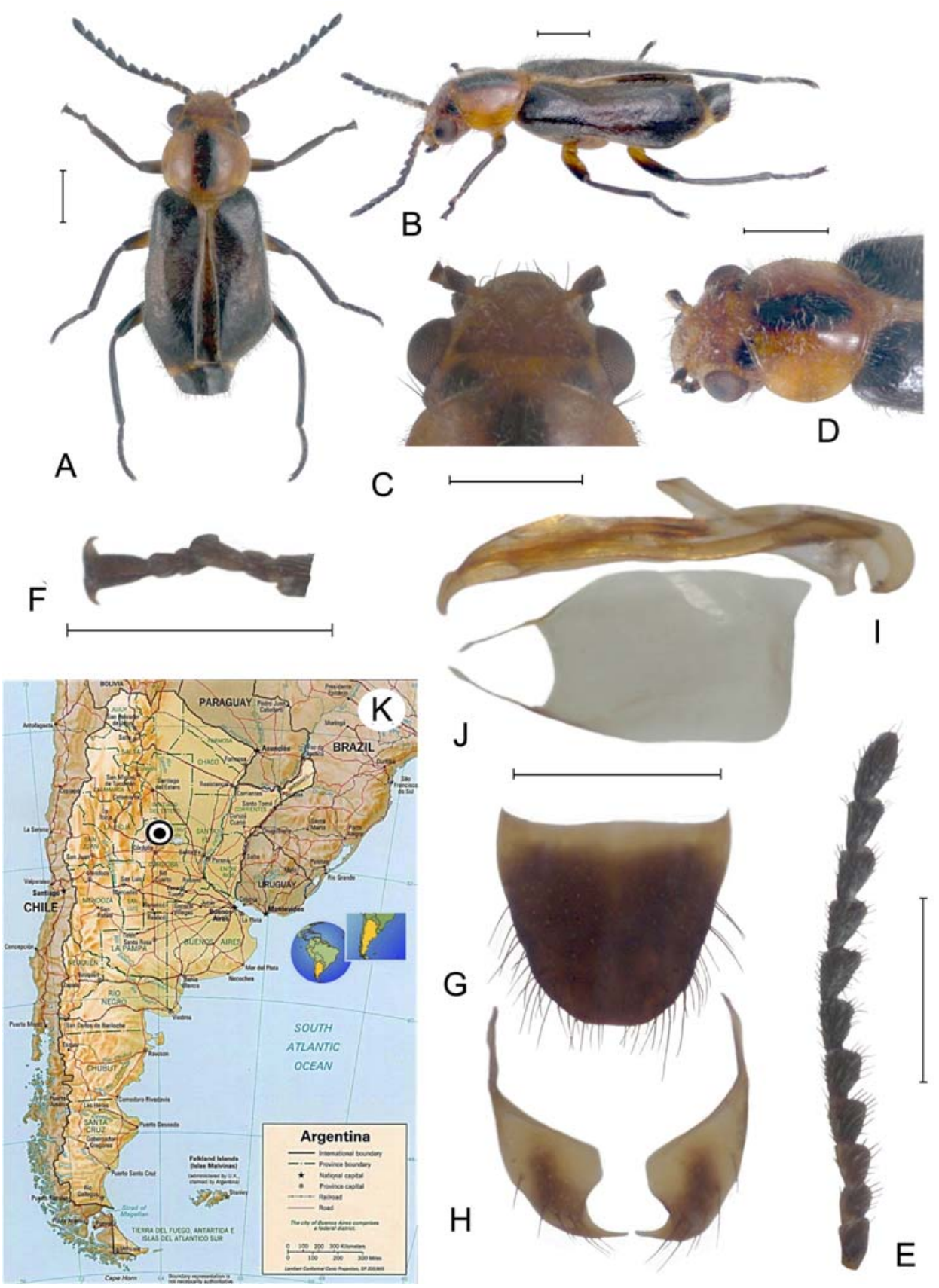

Fig. 1. Attalogonia reshetnikovi Tshernyshev sp.n., holotype, male. A - external appearance, dorsal view; B - external appearance, lateral view; C - head, dorsal view; D - head, pronotum and scutellum, sublateral view; $\mathrm{E}$ - left antenna; $\mathrm{F}$ - right anterior tarsus; $\mathrm{G}$ - apical tergite; $\mathrm{H}$ - apical sternite; I aedeagus, lateral view; $\mathrm{J}$ - tegmen; $\mathrm{K}$ - distribution map. Scale bar $0.5 \mathrm{~mm}$.

Рис. 1. Attalogonia reshetnikovi Tshernyshev sp.n., голотип, male. А - внешний вид дорзально; В внешний вид латерально; C - голова дорзально; D - голова, переднеспинка и щиток латерально; $\mathrm{E}$ - левый усик; F - правая передняя лапка; $\mathrm{G}$ - апикальный тергит; $\mathrm{H}$ - апикальный стернит; I - эдеагус, латерально; J — тегумен; K — карта распространения. Масштаб 0,5 мм. 
Legs thin, not short; posterior femora not reaching elytral apices; all tibiae simple, straight; femora slightly widened and flattened, simple; trochanters simple, lacking teeth; all tarsi 5segmented, intermediate tarsomeres compressed, apical one flattened, not long, 2nd segment in anterior tarsi with transversal distinct comb above, small, but slightly widened and rounded (Fig. 1,F); claw-segment somewhat longer than $1 \mathrm{st}$ and 2 nd together, intermediate tarsomeres subtriangular, 1-3 tarsomeres are equal length, the shortest 4 th one is 1.6 times shorter; claws thin, narrow and sharp, with triangular membrane at base.

Ventral body surface sparsely and finely punctured, dull, evenly covered with fine, adpressed light pubescence; metathorax swollen, simple, lacking appendage of hair tuft, not marginate. Pygidium undivided, elongate, evenly rounded and narrowed distally, densely pubescent (Fig. 1,G); 8th ultimate abdominal ventrite is bilaciniate, each particle tip lamellate and curved vertically, with round hollow between (Fig. 1,H); aedeagus narrow, elongate, simple, slightly curved ventrally at apex, with a pointed triangular lamella at the tip; two strong bristles, one large and wide are along the aedeagus, and the other short disposed in a middle above the long bristle and inner sac, and a group of small denticles near distal side of the upper bristle are visible inside (Fig. 1,J). Tegmen wide, elongate, with short and extremely thin parameres (Fig. $1, \mathrm{I})$.

Length $2.9 \mathrm{~mm}$, width (at elytral base) 1.0 $\mathrm{mm}$.

Female unknown.

DISTRIBUTION. Recorded from type locality only, Quilino environce in Cordoba Province, Argentina (Fig. 1,K).

ETYMOLOGY. This species is named in honour of Sergei Reshetnikov, enthusiast entomologist, who was a member of the expedition to Argentina and has collected this new species.

\section{Acknowledgements}

The author is grateful to Prof. Mark Seaward (Bradford University, U.K.) for the linguistic revi- sion of the text. This study was supported by the Federal Fundamental Scientific Research Programme for 2013-2020, grant No. VI.51.1.5 (AAAA-A16116121410121-7).

\section{References}

Erichson W.F. 1840. Entomographien, untersuchungen in dem Gebiete der Entomologie, mit besonderer Benutzung der Königl // Sammlung zu Berlin. Erstes Heft. III Die Malachien. F.H. Morin, Berlin. S.44-134.

Champion G.C. 1914. Revision of the Mexican and Central American Malachiidae and Melyridae, with descriptions of new species // Transactions of the Entomological Society of London. P.13-127, P1. 2.

Constantin R. 2013. Les Malachiidae et Dasytidae Rhadalinae de Guyane, avec description de douze espèces nouvelles (Coleoptera, Cleroidea) // Coleopteres de Guyane. T.7. P.56-72.

Gorham H.S. 1886. Insecta, Coleoptera, Supplement to Malacodermata. // F.D. Godman, O. Salvin (eds.). Biologia Centrali-Americana. London: Porter. Vol.3. Pt.2. P.313-372, Color plates 6, 7, 12, 13.

Pic M. 1903. Contribution a l'étude des Malachides de l'Amérique méridionale // Annales de la Société Entomologique de Belgique. T.47. P.298-304.

Pic M. 1910. Malachiides exotiques nouveaux [Col. Malacodermata] // Bulletin de la Société Entomologique de France. P.290-292.

Pic M. 1927. Nouveaux Coléoptères exotiques // Entomologische Mitteilungen, Berlin. Bd.16. Ht.4. S.246255.

Pic M. 1928. Malacodermes exotiques // L'Échange, Revue Linnéenne, hors-texte. 44(431, 433-434). P.5356, 61-64, 65-68.

Wittmer W. 1941. Zweiter Beitrag zur Kenntnis der neotropischen Malacodermata // Revista de Entomologia Brasil. Vol.12. No.3. P.507-514.

Wittmer W. 1942. 3me Contribution a la Connaissance des Malacodermes Neotropiques // Revista de la Sociedad Entomológica Argentina. Vol.11. No.3. P.237-239.

Wittmer W. 1976. 35. Beitrag zur Kenntnis der neotropischen Fauna Coleoptera: Fam. Malachiidae // Studia Entomologica. Bd.19. Nos 1-4. S.421-449.

Wittmer W. 1992. 41. Beitrag zur Kenntnis der neotropischen Fauna (Coleoptera: Malachiidae) // Mitteilungen der Schweizerischen Entomologischen. Bd.65. S.95-106.

Tshernyshev S.E. 2016. New Taxa of Soft-winged Flower Beetles (Coleoptera, Malachiidae) in Baltic and Rovno Amber// Paleontological Journal. Vol.50. No.9. P.953962.

Tshernyshev S.E. 2020. New taxa of soft-winged flower beetles (Coleoptera, Malachiidae) in Baltic Amber // Paleontological Journal. Vol.54. No.3. P.631-643.

Responsible editor K.G. Mikhailov 